\title{
Potensi Penambahan Azolla sp. dalam Formulasi Pakan Ikan Lele (Clarias sp.) Terhadap Retensi Energi dan Rasio Konversi Pakan
}

\author{
A Potential of Azolla sp. inclusion in Catfish (Clarias sp.) Feed Formulation \\ Againts Energy Retention and Feed Conversion Ratio. \\ Puji Hariyanti $^{1 *}$, Prayogo $^{2}$, dan Mirni Lamid ${ }^{2}$
}

\author{
${ }^{1}$ Budidaya Perairan, Fakultas Perikanan dan Kelautan Universitas Airlangga, Surabaya 60115 \\ ${ }^{2}$ Departemen Kelautan, Fakultas Perikanan dan Kelautan Universitas Airlangga, Surabaya 60115 \\ *pujihariyanti12@yahoo.co.id
}

\begin{abstract}
Abstrak
Ikan lele (Clarias sp.) merupakan ikan konsumsi dan komoditas sektor perikanan air tawar yang terus berkembang pesat. Ikan lele termasuk ikan yang paling mudah diterima masyarakat karena berbagai kelebihannya. Kelebihan tersebut diantaranya adalah pertumbuhannya cepat, memiliki kemampuan beradaptasi terhadap lingkungan yang tinggi, rasanya enak dan kandungan gizinya cukup tinggi serta harganya murah. Salah satu faktor yang menentukan keberhasilan budidaya ikan adalah ketersediaan pakan yang memadai, baik kuantitas maupun kualitas. Ada beberapa alternatif bahan pakan yang dapat dimanfaatkan dalam penyusunan pakan, salah satu bahan pakan tersebut adalah tepung azolla yang berbahan dasar tanaman Azolla sp. Pemilihan bahan dasar pakan menggunakan Azolla sp. didasari hasil penelitian Handajani (2000) yang menyatakkan bahwa kandungan protein Azolla sp. yang cukup tinggi, yaitu 28,12\% berat kering. Penambahan Azolla sp. dalam formulasi pakan ikan lele diharapkan dapat meningkatkan retensi energi dan menurunkan rasio konversi pakan. Tujuan dari penelitian ini adalah untuk mengetahui penambahan Azolla sp. dalam formulasi pakan berpengaruh terhadap retensi energi dan rasio konversi pakan ikan lele. Penelitian ini dilaksanakan pada bulan Juli - Agustus di Fakultas Perikanan dan Kelautan, Universitas Airlangga. Metode penelitian yang akan digunakan adalah metode eksperimental dengan rancangan acak lengkap. terdiri atas lima perlakuan dan empat kali ulangan. Perlakuan yang digunakan adalah penambahan tepung azolla $0 \%, 5 \%, 10 \%, 15 \%$ dan $20 \%$ pada pakan. Analisis data yang digunakan adalah statistik dan deskriptif. Hasil penelitian menunjukkan bahwa retensi energi antar perlakuan tidak berbeda nyata dan rasio konversi pakan tidak berbeda nyata. Hasil penelitian dapat disimpulkan penambahan Azolla sp. dalam formulasi pakan ikan lele tidak memberikan pengaruh terhadap retensi energi dan rasio konversi pakan.
\end{abstract}

Kata Kunci : Azolla sp., Ikan Lele, Retensi Energi, Rasio Konversi Pakan

\begin{abstract}
Catfish is one of the fish that has a high economical value. Catfish is accepted by society easily because of its advantages. These advantages include fast growing, good adaptive behavior, good taste, high nutrient, and cheap price. One of the factors that determine the success of aquaculture is the availability of adequate food, both quantity and quality. There are several alternative feed ingredients that can be used in the preparation of feed. One of these feed ingredients is azolla flour made from Azolla sp. plant. Azolla sp. plant contains large amount of protein up to $28,12 \%$ of its dried weight. Selection of the base material feed using Azolla sp. based on the research results Handajani (2000) which declare that the protein content Azolla sp. which is quite high, namely 28.12\% dry weight. The addition of Azolla sp. in catfish feed formulation is expected to improve retention of energy and lower feed conversion ratio. The purpose of this study was to determine the addition of Azolla sp. in feed formulations affect the retention of energy and feed conversion ratio catfish. This research was conducted in JulyAugust in the Faculty of Fisheries and Marine University Airlangga. Research method used in the study was an experimental method with complete random planning. It included five treatments and four repetitions. Treatments that were used included azolla flour inclusion 0\%, 5\%, 10\%, 15\% and 20\% at the formulated feed. Data analysis that was used included statistic and descriptive. The result of the research shows that energy retention among treatments does not have significant difference. On the other hand, the feed conversion ratio also does not have significant difference. It can be concluded that Azolla sp. inclusion in the catfish feed formulation affects nothing to energy retention and feed conversion ratio.
\end{abstract}




\section{Pendahuluan}

Ikan lele (Clarias sp.) merupakan salah satu komoditas perikanan yang permintaanya mengalami peningkatan setiap tahunnya (Astawan, 2008). Ikan ini berasal dari benua Afrika dan pertama kali didatangkan ke Indonesia pada tahun 1984. Ikan lele termasuk ikan yang paling mudah diterima masyarakat karena berbagai kelebihan, antara lain adalah memiliki pertumbuhan cepat, dapat beradaptasi terhadap lingkungan yang kurang baik, rasanya enak dan kandungan gizinya cukup tinggi. Pertumbuhan ikan salah satunya dipengaruhi oleh kualitas pakan. Jumlah pakan atau tingkat pemberian pakan yang dikonsumsi oleh ikan sangat berpengaruh terhadap pertumbuhan. Mahalnya harga pakan ikan dan rendahnya harga jual ikan air tawar merupakan masalah besar dalam pengembangan budidaya ikan lele. Faktor pakan menentukan biaya produksi mencapai 60 - 70\% dalam usaha budidaya ikan sehingga perlu pengelolaan yang efektif dan efisien (Handajani, 2008).

Salah satu upaya untuk mengatasi masalah bagi para pembudidaya ikan adalah dengan penyediaan pakan buatan sendiri yang berkualitas dengan berbasis bahan baku lokal. Bahan baku lokal tersebut harus memiliki persyaratan, yaitu terjaga kuantitas dan kualitas, mudah diperoleh, ekonomis serta tersedia sepanjang waktu (Panduwijaya, 2007). Formulasi merupakan faktor yang paling berpengaruh dalam pembuatan pellet karena formulasi merupakan langkah awal penentuan berapa jumlah bahan yang digunakan untuk menghasilkan protein yang dikehendaki (Handajani, 2008). Ada beberapa alternatif bahan pakan yang dapat dimanfaatkan dalam penyusunan pakan. Salah satu bahan pakan tersebut adalah tepung azolla yang berbahan dasar tanaman Azolla sp.

Tanaman Azolla sp. merupakan gulma air atau hijauan air yang tumbuh di sawah atau kolam di daerah tropis yang bernilai gizi tinggi untuk dijadikan pakan ikan. Handajani (2008) yang menyatakkan bahwa kandungan protein Azolla sp. yang cukup tinggi, yaitu $28,12 \%$ berat kering. Menurut Buwono (2000), kebutuhan protein pada ikan berkaitan erat dengan kebutuhan energi total. Keseimbangan antara energi dan kadar protein sangat penting dalam laju pertumbuhan. Apabila ransum mengandung energi yang rendah, maka ikan akan menggunakan sebagian protein untuk memenuhi kebutuhan energinya. Retensi energi merupakan gambaran dari banyaknya energi yang tersimpan dalam bentuk jaringan di tubuh ikan dibagi dengan banyaknya energi dalam 
pakan yang dikonsumsi (Hariati, 1989). Penambahan Azolla sp. diharapkan dapat meningkatkan retensi energi pada ikan lele.

Nilai rasio konversi pakan yang semakin tinggi menunjukan bahwa semakin rendah efisiensi pakannya atau nutrien terbuang dalam feses (Yuniarti dkk., 2002). Penambahan Azolla sp. dalam formulasi pakan diharapkan mampu menurunkan rasio konversi pakan pada ikan lele.

\section{Materi dan Metode}

Penelitian ini dilaksanakan pada bulan Juli sampai bulan Agustus 2016 di Laboratorium Basah, Fakultas Perikanan dan Kelautan Universitas Airlangga, Surabaya. Analisis Proksimat pakan dan daging ikan lele dilakukan di Laboratorium Pakan Fakultas Kedokteran Hewan Uiversitas Airlangga, Surabaya.

\section{Alat dan Bahan}

Alat yang digunakan meliputi akuarium $40 \times 25 \times 25 \mathrm{~cm}^{3}$ sebanyak 20 buah, selang aerasi, batu aerasi, aerator, seser, timbangan digital, $\mathrm{pH}$ papper, termometer, DO test, amoniak test, alat sipon, tandon.

Hewan uji yang digunakan dalam penelitian adalah ikan lele (Clarias sp.) dengan ukuran 9-10 $\mathrm{cm}$, umur \pm 1 bulan dan masuk dalam fase pendederan. Kepadatan ikan lele 10/15 Liter. Jumlah perlakuan dalam penelitian ini adalah 5 perlakuan dan
4 ulangan sehingga membutuhkan 200 ekor ikan. Pakan yang digunakan adalah pakan formulasi dengan menambahkan tepung azolla sebagai bahan penyusun pakan.

\section{Prosedur Penelitian}

Peralatan yang akan digunakan dalam penelitian dicuci terlebih dahulu, pencucian menggunakan sabun dan dibilas hingga bersih kemudian dikeringkan dan diisi dengan air tawar lalu dipasang aerasi selama 24 jam untuk meningkatkan oksigen terlarut (DO). Ikan gurami diseleksi sebelum ditebar pada akuarium, seleksi berdasarkan keseragaman ukuran dan kelengkapan organ tubuh sehingga dapat dipastikan bahwa ikan lele yang akan diteliti adalah ikan lele yang sehat dan homogen. Sebelum ditebar, ikan lele diaklimatisasi terlebih dahulu selama 30 menit. Penebaran ikan lele dilakukan pada pagi atau sore hari untuk menghindari terjadinya stress yang dapat berakibat pada kematian.

Tanaman Azolla sp. diperoleh dari kolam Instalasi Budidaya Air Tawar (IBAT) Punten, Malang, Jawa Timur, langkah pertama yaitu Azolla sp. diambil dari kolam, dicuci bersih kemudian dikeringkan atau dijemur dibawah sinar matahari langsung selama kurang lebih 3 hari. Azolla kering kemudian ditimbang berat keringnya dan digiling halus untuk dijadikan tepung azolla. 
Bahan pakan lainnya antara lain tepung ikan, bungkil kedelei, jagung, dan dedak padi yang masih kasar diayak terlebih dahulu menggunakan saringan, sehingga diperoleh bahan yang halus sebelum dicampur. Bahan pakan yang telah diayak kemudian ditimbang sesuai dengan formulasi. Setelah ditimbang bahan tersebut dicampur menjadi satu hingga merata. Bahan yang berbentuk tepung dicampur dari yang jumlahnya paling kecil dahulu, kemudian diikuti yang lebih besar dan seterusnya. Bahan yang sudah tercampur setelah itu diberi mineral dan setelah itu dicetak dengan menggunakan mesin penggiling pellet. Pakan buatan yang sudah setengah jadi baru dikeringkan dengan menggunakan oven dengan suhu 60 ${ }^{\circ} \mathrm{C}$ selama 24 jam. Pakan yang telah kering dianalisis proksimat untuk melihat kandungan protein, lemak, BETN, serat kasar dan abu.

\section{Analisis Data}

Data yang diperoleh dari hasil penelitian akan dianalisis menggunakan Analisis of Variance (ANOVA). Uji lanjut yang digunakan adalah Uji Jarak Berganda Duncan (Duncan's Multiple Range Test) dengan taraf nyata 5\% untuk mengetahui apakah terdapat pengaruh antar perlakuan dengan penambahan lisin pada pakan komersial terhadap retensi energi dan rasio konversi pakan pada ikan gurami. (Kusriningrum, 2015).

\section{Hasil dan Pembahasan}

a. Retensi Energi

Hasil penelitian menunjukkan nilai retensi energi ikan lele berkisar antara 20,45 - 28,39 \%. Data rata-rata retensi energi dapat dilihat pada Tabel 1.

Tabel 1. Rata- Rata Retensi Energi Ikan Lele (\%)

\begin{tabular}{cc}
\hline Perlakuan & Retensi Energi $(\%)$ \\
\hline $\mathrm{P}_{0}$ & $21,96 \pm 5,02$ \\
$\mathrm{P}_{1}$ & $25,55 \pm 8,20$ \\
$\mathrm{P}_{2}$ & $28,39 \pm 3,37$ \\
$\mathrm{P}_{3}$ & $24,05 \pm 2,89$ \\
$\mathrm{P}_{4}$ & $20,45 \pm 8,28$ \\
\hline
\end{tabular}

Keterangan Superscript yang sama pada kolom yang sama menunjukan tidak berbeda nyata pada uji Jarak Berganda Duncan's Multiple Range Test ( $\mathrm{p}>0,05)$.

Hasil analisa statistik penambahan Azolla sp. dalam formulasi pakan menunjukkan hasil yang tidak berbeda nyata $(p>0,05)$ terhadap retensi energi ikan lele. Data hasil analisa statistik ANOVA dapat dilihat pada Lampiran 10 . Berdasarkan Uji Jarak Berganda (Duncan's Multiple Range Test) tidak ada perbedaan yang nyata antar perlakuan $\mathrm{P}_{0}, \mathrm{P}_{1}, \mathrm{P}_{2}, \mathrm{P}_{3}$ dan $\mathrm{P}_{4}$.

$$
\text { Retensi energi merupakan }
$$
gambaran dari banyaknya energi yang tersimpan dalam bentuk jaringan di tubuh ikan dibagi dengan banyaknya energi dalam pakan yang dikonsumsi (Hariati, 1989). Retensi energi (RE) menunjukkan besarnya kontribusi energi pakan yang dikonsumsi 
terhadap pertambahan energi tubuh ikan dan dapat di simpan di dalam tubuh.

Hasil uji statistik ANOVA menunjukkan bahwa penambahan Azolla sp. dalam formulasi pakan menunjukkan hasil yang tidak berbeda nyata $(p>0,05)$ terhadap retensi energi ikan lele (Clarias sp.). Kandungan energi pakan P0 sebesar (2972,01), P1 (2973,54), P2 (3006,50), P3 $(2913,24)$, P4 (2900,37), Sehingga energi yang diserap pada tubuh ikan relatif sama nilainya.

Peningkatan nilai retensi energi cenderung terjadi pada P2 dikarenakan berdasarkan perhitungan data pakan yang dikonsumsi P2 menghasilkan nilai konsumsi pakan yang tinggi yaitu sebesar 94,24 gr dengan retensi energi sebesar $28,39 \%$. Data perhitungan konsumsi pakan dapat dilihat pada Lampiran 6. Retensi energi pada $\mathrm{P} 2$ yaitu sebesar $28,39 \%$ hal ini menunjukan bahwa dengan penambahan dosis Azolla sp. dalam formulasi pakan ikan lele sebesar $10 \%$ mengakibatkan konsumsi pakan meningkat yaitu sejumlah 94,24 gr dibandingkan dengan dosis Azolla sp. pada perlakuan lainnya. Meningkatnya jumlah konsumsi pakan mengakibatkan lebih banyak nutrien yang terserap oleh tubuh.

Retensi energi pada P4 sebesar $20,45 \%$ dengan perhitungan konsumsi pakan yang paling rendah yaitu sebesar 78,87 gr hal ini menunjukan bahwa pemberian azolla $20 \%$ dapat meningkatkan protein pakan sebesar 40,32 namun retensi energinya menjadi menurun dikarenakan protein dan energi dalam pakan jika tidak seimbang akan mengakibatkan pertumbuhan ikan menjadi tidak optimal karena protein yang berlebihan menyebabkan ikan memerlukan energi ekstra untuk melakukan proses deaminasi sehingga energi yang seharusnya digunakan untuk pertumbuhan akan berkurang. Hal ini sesuai dengan pendapat Haetami (2007), ransum yang tidak mempunyai keseimbangan energi-protein yang tepat tidak akan berdampak pada pertumbuhan, jika tingkat energi protein melebihi kebutuhan maka akan menurunkan konsumsi sehingga pengambilan nutrien lainnya termasuk protein akan menurun.

Menurut Lan dan Pan (1993) apabila protein dalam pakan berlebih ikan akan mengalami 'excessive protein syndrome', sehingga protein tersebut tidak digunakan untuk pertumbuhan tetapi akan dibuang dalam bentuk amonia. Semakin banyak protein yang disintesa oleh tubuh maka semakin banyak energi yang digunakan. Hal ini menyebabkan protein yang seharusnya tersimpan akan lebih banyak dirubah menjadi energi untuk mensintesa kelebihan protein menjadi amonia.

\section{b. Rasio Konversi Pakan}


Hasil penelitian menunjukkan rasio konversi pakan ikan lele berkisar antara 3,43 - 4,86. Data jumlah pakan yang dikonsumsi ikan lele selama pemeliharaan 28 hari dapat dilihat pada Lampiran 6. Data rata-rata rasio konversi pakan dapat dilihat pada Tabel 5.

Tabel 5. Rata- Rata Rasio Konversi Pakan Ikan Lele

Perlakuan Rasio Konversi Pakan

\begin{tabular}{ll}
\hline $\mathrm{P}_{0}$ & $4,28 \pm 1,63$ \\
$\mathrm{P}_{1}$ & $3,88 \pm 1,66$ \\
$\mathrm{P}_{2}$ & $3,43 \pm 0,43$ \\
$\mathrm{P}_{3}$ & $4,75 \pm 1,72$ \\
$\mathrm{P}_{4}$ & $4,86 \pm 1,53$ \\
\hline
\end{tabular}

Keterangan: Superscript yang sama pada kolom yang sama menunjukan tidak berbeda nyata pada uji Jarak Berganda Duncan's Multiple Range Test $(\mathrm{p}>0,05)$.

Hasil analisa statistik penambahan Azolla sp. dalam formulasi pakan menunjukkan hasil yang tidak berbeda nyata $(p>0,05)$ terhadap rasio konversi pakan ikan lele pada semua perlakuan.

Nilai rasio konversi pakan berbanding terbalik dengan pertumbuhan bobot ikan. Nilai rasio konversi pakan yang semakin tinggi menunjukkan bahwa pakan yang diberikan semakin tidak efektif dalam pertumbuhan ikan lele (Clarias sp) (Mudjiman, 2002).

Hasil uji statistik ANOVA yang dilanjutkan dengan uji Jarak Berganda Duncan (Duncan's Multiple Range Test) menunjukkan bahwa penambahan Azolla sp. dalam formulasi pakan ikan tidak mempengaruhi nilai rasio konversi pakan ikan lele $(p>0,05)$. Hal ini disebabkan oleh tidak semua pakan yang diberikan menjadi daging, ada bagian dari pakan yang dikeluarkan sebagai feses atau lainnya. Handajani dan Widodo (2010) menyatakan bahwa tidak semua energi yang masuk dapat dicerna dan dimanfaatkan untuk pertumbuhan.

Berdasarkan perhitungan hasil rasio konversi pakan $\mathrm{P} 2$ adalah 3,43 yang artinya 3,43 gram pakan akan memberikan penambahan berat ikan lele sebanyak 1 gram. Nilai rasio konversi pakan P4 yaitu 4,86 yang artinya 4,86 gram pakan akan memberikan penambahan berat ikan lele sebanyak 1 gram. Semakin besar nilai rasio konversi pakan, maka semakin banyak pakan yang dibutuhkan. Menurut Effendy (2004) nilai konversi pakan yang baik adalah kurang dari 2 yang artinya dalam memberikan pakan sebanyak kurang dari 2 $\mathrm{kg}$ akan menghasilkan daging ikan sebanyak $1 \mathrm{~kg}$. Rata-rata nilai rasio konversi pakan pada penelitian ini termasuk tinggi. Menurut mudjiman (2002), pakan yang tidak tercerna atau jenis pakan yang kurang disukai merupakan faktor penyebab rasio konversi pakan tinggi.

\section{Kesimpulan dan Saran}

Penambahan tepung Azolla dengan pemberian hingga $20 \%$ pada formulasi pakan tidak dapat meningkatkan retensi energi ikan lele (Clarias sp. Penambahan tepung Azolla hingga 20\% pada formulasi 
pakan tidak dapat menurunkan rasio konversi pakan pada ikan lele (Clarias sp.). Saran yang dapat diberikan untuk pembudidaya dan pembuat pakan adalah perlu dilakukan penelitian lebih lanjut tentang kualitas dan formulasi dosis tepung Azolla yang tepat agar terjadi keseimbangan protein dan energi pada pakan sehingga dapat meningkatkan retensi energi dan menurunkan rasio konversi pakan ikan lele (Clarias sp.)

\section{Daftar Pustaka}

Afrianto, E dan E. Liviawaty. 2005. Pakan Ikan. Kanisius. Yogyakarta. Hal 3740.

Buwono I. D. 2000. Kebutuhan Asam Amino Esensial Dalam Ransum Ikan. Kanisius. Yogyakarta. Hal 916.

Effendi, M.I. 2004. Biologi Perikanan. Yayasan Pustaka Nusantara. Yogyakarta. 165 hal.

Handajani, H. 2000. Peningkatan kadar protein tanaman Azolla microphylla dengan mikrosimbion Anabaena azollae dalam berbagai konsentrasi $\mathrm{N}$ dan $\mathrm{P}$ yang berbeda pada media tumbuh. Hal 177-181.

Handajani, H. 2008. Pengujian Tepung Azolla Terfermentasi Sebagai Penyusun Pakan Ikan Terhadap Pertumbuhan dan Daya Cerna Ikan Nila Gift. Naskah Publikasi Fakultas Peternakan Perikanan. Universitas Muhammadiyah. Malang. Hal 162-170.
Handajani, H. dan W. Widodo. 2010. Nutrisi Ikan. Universitas Muhammadiyah Malang press. Malang. Hal 34.

Hariati, A.M. 1989. Makanan Ikan. Universitas Brawijaya. Fish Fisheries Project Malang. 99 Hal.

Kordi, M. G. 2005. Budi Daya Ikan Lele di Kolam Terpal. Yogyakarta: Lily Publisher. Hal 20-22.

Kusriningrum. 2015. Perancangan Percobaan. Universitas Airlangga Press. Surabaya.

Lan, C.C dan B.S. Pan. 1993. Invitro Ability Stimulating The Proteolysis of Feed Protein in The Midgut Gland of Grass Shrimp (Pannaeus monodon). Aquaculture 109:59-70.

Mudjiman, A. 2002. Makanan Ikan. Penebar Swadaya. Jakarta

Panduwijaya, J. 2007. Pengaruh Kadar Protein Terhadap Efisiensi Pemberian dan Efisiensi Biaya Pakan Lele Dumbo (Clarias gariepinus). Skripsi. Program Studi Perikanan Fakultas Perikanan dan Ilmu Kelautan, Universitas Padjadjaran. Jatinangor. Hal 25.

Yuniarti, A., A. M. Hariyati dan E. Sanusi. 2002. Teknologi silase dengan starter bakteri asam laktat untuk pertumbuhan dan deposisi protein ikan lele dumbo (Clarias gariepinus). Jurnal Ilmu Ilmu Hayati. 14 (I) :42-49. 